\title{
Social Pathologies of Communication
}

\section{Pascal Durand}

Translator. Inist

\section{OpenEdition}

\section{Journals}

Electronic version

URL: https://journals.openedition.org/questionsdecommunication/8881

DOI: 10.4000/questionsdecommunication.8881

ISSN: 2259-8901

\section{Publisher}

Presses universitaires de Lorraine

\section{Printed version}

Date of publication: 1 July 2009

ISBN: 978-2-86480-989-0

ISSN: 1633-5961

\section{Electronic reference}

Pascal Durand, "Social Pathologies of Communication", Questions de communication [Online], 15 |

2009, Online since 01 February 2014, connection on 21 September 2021. URL: http://

journals.openedition.org/questionsdecommunication/8881; DOI: https://doi.org/10.4000/

questionsdecommunication.888

This text was automatically generated on 21 September 2021.

Questions de communication is licensed under CC BY-NC-ND 4.0

$(1) \odot \ominus$ 


\title{
Social Pathologies of Communication
}

\author{
Pascal Durand
}

Translation : Inist

\section{EDITOR'S NOTE}

This English translation has not been published in printed form/Cette traduction anglaise n’a pas été publiée sous forme imprimée.

In the absence of English language edition, a lot of the quotes have been translated by the Inist.

1 Focusing not on the virtues but on the vices of communication; examining, through associated pathologies - and social pathologies especially - not the ways and means of communication, but the deviations that may stem in part from communication; considering communication not as a way of preventing or reducing of these pathologies but as a possible vector of a circular process of aggravation: these, briefly, are the outlines of this issue of Questions de communication. Quite a task: a few articles on the subject would hardly have sufficed to cover, or even map out, a topic that could range, if we go by received ideas, from addiction to the electronic world and the syndromes of derealisation and isolation triggered by virtual technologies, to propaganda systems and other techniques for air-brushing political or social conflicts. But it is also a task that may seem rather incongruous given the mantras surrounding our conceptions of communication and the doxa that has established communication not only as an active ingredient of social life generally, but also as a vital resource whose value is indisputable.

2 The "social pathology" idea is obviously a nod in the direction of the Frankfurt School, where it is linked in particular to the revival of critical theory inspired by the philosopher Axel Honneth, who succeeded Jürgen Habermas at the helm of the Social Research Institute. It is well known that, in the general definition offered by Honneth in La Société du mépris, the idea covers the full range - varying as it does with different social cultures 
and conditions - of "social relations or changes that, for everyone, affect the conditions of self-realisation" (Honneth, 2006: 179). The reality of inequality and injustice, the hardships of social conditions and positions, the pressures of performance and mobility, for example, are not only, from this point of view, difficult situations in which social subjects may find themselves but which remain outside their mental and bodily sphere, but actual pathogenic agents liable to invade their intimacy and infect their inner self, where they can trigger particular disorders and place those affected - to different degrees, although it is unlikely that anyone is entirely unaffected - in a neurotic relationship with themselves as well as with the collective spheres to which they belong. Referring to the social pathologies of communication, where communication itself is taken as the source of particular pathologies, therefore creates a double paradox, which the authors of the contributions that follow, from different sectors of our "inter-discipline", have willingly taken on board. The paradox on the one hand is central to the very notion of "social pathologies", in the sense that these refer to disorders and afflictions for which communication - identified here in accordance with Jürgen Habermas, who sees it as the normative core of society, an active resource for shared understanding and rationality is usually seen as a means of prevention or cure. But the paradox also concerns communication itself or, to be more specific, what society agrees to refer to as "communication" - a rather loose term for which, in the pages that follow, the inverted commas used here should be kept in mind.

It has become a commonplace to observe that the word "communication" covers a wide variety of fields and levels of analysis, of phenomena and points of view, of fields of investigation and theoretical corpuses, of concepts and methods. Less commonplace is to say that it also covers a tangled web of descriptive observations - for example, "one cannot not communicate", as Paul Watzlawick maintained - as well as a prescriptive dimension: we have to communicate, you have to keep informed, everyone has to be in tune with their times and interact in harmony with others, etc. Communication, then, is at once an object (or a complex of highly varied objects) and discourse on that object (or on objects that sometimes substitute for each other according to need); at once an inhabited world (as a matrix of society) and a means of confinement in that world; at once a discipline that operates at the point of intersection between different sectors of the humanities, the applied sciences and one sector of market production (or an auxiliary sector for others in this type of production); at once a value, subtly enforced but obligatory nonetheless, and the work involved in imposing consensus on that value; at once a set of practices that can be problematised for scientific study and a series of strictly ideological issues. In the latter, it is striking to observe that communication, boiled down to a purely iconic term and an addictive reflex, tends to be used as both a panacea and an alibi in mainstream political and media discourse, as when leader writers and decisionmakers start interpreting - and naming - social conflicts, resistance to "change" and "reforms" or the "failure" of the EU referendum, in terms of a "communication deficit" (or "learning deficit") between "partners" who have unequal information about the constraints and opportunities of an "increasingly complex world" (on these various clichés, see Durand, 2007). The author of an anthology of the information and communication sciences was quite right to say - perhaps too incidentally - that "the invasive phraseology [of communication] is the opium of our time" (Bougnoux, 1993: 10). Indeed it is, a tediously anaesthetising phraseology used to discuss the psychosocial and political virtues of communication - through expressions like "establishing relationships", "connections", "intercomprehension", "reliance", and so on and so forth - 
in a discourse whose circularity is fully equal to the soporific properties of any opiate. "Problems necessarily appear as soon as communication is seen as the solution to everything", as Yves Winkin remarked when introducing a polemical essay that took on not only the degraded variants of the theoretical models used in the communication sciences proper - variants as exemplary as NLP or the methods for reading facial expressions popularised by a certain Paul Ekman - but also the danger for those same sciences, in an increasingly heteronomous academic world, of being pressed into the service of commercial, entrepreneurial or political demands; "although", he adds, "solutions can come within reach as soon as communication is seen as a problem" (Winkin, 2003: 15).

4 Taking an unambiguously critical view of communication - its theoretical difficulties, its definitions and intuitive representations, or the eschatology and highly affirmative theology in which it surrounds itself in times when "ideologies" are supposedly in retreat and the main symbolic "thirds" on the verge of collapse - is obviously not new, as shown by the efforts of Lucien Sfez to dismantle scholarly constructions and their utopian pillars in his imposing Critique de la communication (1988) and his Dictionnaire critique de la communication (1993), which he pursues in Technique et idéologie (2002). It should also be borne in mind that this kind of criticism does not always enjoy the company of such eminent thinkers, and that, for example, the weighty metaphor with its obsessively repeated themes of "suggestion", "contagion" and "contamination" was the means used by the ideologue-cum-psychologist Gustave Le Bon (1895), in the latter half of the 19th century, to promote his ideas on how the propagation of the affect and of the emotions produces "the popular mind", a state in which a crowd becomes an organism in itself where physical proximity invariably whips up sentiment to the point of obliterating individual free will. From this reactionary view of communication as a means of fuelling mass hysteria developed, perhaps for the first time, the idea of a social pathology at work not only in mass movements but also in the democracy of universal suffrage. Nor should we forget the symbolic gratification and the philosophical kudos derived from taking a stance on an object of common interest that manifestly challenges common wisdom. Adorno and Horkheimer, in Dialectic of Enlightenment (1944) on the entertainment industry, or, more recently, Paul Virilio in his Politics of the Very Worst [Cybermonde. La Politique du pire (1996)] on the changes in tempo and acceleration of techno-political developments, thus held views diametrically opposed to the reassuring, clichéd norm, showing how the emancipating power of reason will tend, in a technologically governed society, to turn into its exact opposite - alienation, mystification, conditioned minds reverting to the magic of the never-ending cycle that makes time stand still - and how the universal interconnection of information networks presaging the planetary breakdown of information has virtually doomed democracy to extinction through excessive control over our minds and the sheer speed of data traffic. An overshadowing, elitist and therefore minority view, which is fundamentally questionable and irritating no doubt, but less exasperating and certainly less likely to affect social practice and political choices than the semi-scholarly mantras, slogans and clichés that redundantly permeate today's omnipresent discourse on "the information society", the "virtual economy" or the "knowledge society".

5 In the first volume of his Memoirs, describing the mythical America that had already pervaded the clearest minds, Talleyrand (Jean de Bonnot 1967: 71) maintained that "the spirit of destruction" rushes in whenever communication becomes easier. At about the 
same time, around 1830, Chateaubriand (1848, t. II: 662) - greatly exercised as well as prophetic about Germany's modernisation, which he believed could only serve the purposes of war ${ }^{1}$ [French quote in end-of-page note] - wrote with savage irony about the rapturous admiration of modern ways he saw among his contemporaries ${ }^{2}$ [ditto] (ibid.: 527). He himself would not be dazzled by "steamships and railroads", the selling of manufactured goods and the wealth amassed by a few French, English, German or Italian soldiers in the service of Turkish masters, for that "is not spreading civilisation" 3 [ditto] (1848, t. I. : 877). Thus speaks the aging cynic, doddering on the brink of a world no longer his own, in the banal language of reactionary sentiment and petulant romanticism that clearly stems from his rejection, like Talleyrand's, of a modernity where the technical and the political have become inseparable. These postures that we feel belong to a different age at least have the merit of reminding us, should the idea come to mind, of what the communicational ideology of our own time tends to make us forget or ignore: that communication, whether in the plural or the singular - which dilutes it into the anthropological approach or simply into a social phenomenon - is, is also, a technique that serves the interests of the powers that be: in its physical forms from Roman roads to the motorways of modern Germany, from semaphore to the word wide web, communication is inseparable from every system of intervention, surveillance and control, from military systems serving the power of the State to economic and trade networks and today's equally market-based circulation of virtual information and entertainment. These successive metamorphoses of modernity, up to our times, into manifestations of the natural order or serendipitous innovation, can be usefully placed in a historical perspective: as in any form of modernity, its characteristics are the amnesia surrounding its origins and the illusion it conveys of responding to a compulsion driven purely by the power and inevitability of its own emergence. There is little doubt, for example, that Chateaubriand, in his vituperations on the "model society", was, in barely disguised terms, attacking the "industrialist" doctrine of the Saint-Simon school, based on a theory of communication networks, that took root from 1830 to 1840 in progressive circles until its conversion in support of the technocratic State during the second French empire, through the good offices of Michel Chevalier, the first Chair of political economics at the College de France who in 1851 joined the imperial cause as advisor to Napoleon III on these matters. It is worth remembering that the development of transport systems and communication technologies went hand in hand, throughout the 19th century whose legacy is still very much with us today, with the mystique of its association with the universal peace that networks could bring (see Musso, 1997; 2003). It is also worth pointing out that the paradoxical counterpoint to this mystique, its reflection in the negative in both politics and mindsets, was the gradual establishment of conditions that would make a fragmented, partitioned, modular?? society possible against a backdrop of dissolution, virtually at least, of class groups and class solidarity based on the fiction of a social fabric woven from abstract, universal, interchangeable and cumulative parts, a fiction whose principle - the secret ballot, a technique serving secrecy and isolation at once - was realised, symbolically and in practice, on the eve of the first World War (see Garrigou, 1998). The adoption of opinion polls, among other American imports, would confirm, in Sartre's view, that the systemic nature of "technological civilisation" implies in itself that individuals are interchangeable, juxtaposed units that have to be merged into an organic whole. As he wrote in 1983:

"This is where we are heading with the mass media, the best seller, the book of the month, the best record, Gallup, Oscar, etc. The idea is to present a single exemplar 
with an image of the whole. Of course this only produces an image of the majority, but the majority is given as the expression of the whole [...] Opinion remains outside, it is the ideal and transcendent point where all conscience meets, but because it is transcendent, it leaves each conscience entirely alone with itself, without the words or concepts to express itself". ${ }^{4}$ (Sartre, $\left.1983: 93\right)^{5}$

Utopian dreams of universal togetherness waved into being by the political magic wand of networks and communications thus converged towards the idea of a society tending wholly or partly towards anomie - a concept forged by Jean-Marie Guyau in his Esquisse d'une morale sans obligation, ni sanction (1885) to define a morality that could suit a time when the foundations of authority were collapsing (religion, the State, science), and in which Émile Durkheim (1897: 264-311), in his study of suicide [Le suicide], would see a type of pathology triggered by crisis and, more generally, by the state of a society where those of its members who are cut off from one another by an excessive division of labour are condemned to perpetual mobility and uncertainty, with the loss of their sense of interdependence.

7 The point of this convoluted back-tracking through history, with its meanderings into the genealogical byways of mutually reinforcing links between technology and technological myth and between the development of communication(s) and the process of social serialisation, is not merely to dispel the euphoria of ideas and representations ordinarily associated with communication and thereby to create a space for different perspectives on the pathological conditions that communication(s), contrary to general belief, might cause. The idea is also to establish the retrospective horizon that the article by David Forest, in this issue, helps to define. The "collective intelligence" he dissects is one of the new clichés that have found their way into Utopian conceptions of communication: yet another example of those secular prophecies flavoured as much by mystic fervour as by cold utilitarianism, accompanied by the familiar discourse on "new technologies", on which he has already published a robust analysis (Le Prophétisme communicationnel, 2004). It is well known that the expression, soon to be incorporated into the journalistic technolect and whose emergence coincided in France with day-to-day internet use, was coined by Pierre Lévy, the promoter of an "anthropology of cyberspace" and of a view of humanity where the monadic individuals of a grid-mapped society would give way to free nomadic circulation within a "global brain": will the "information highways" and "multimedia" widen the gap between rich and poor, between the in-crowd and the rest? This is, he admitted, one possibility for the future. But if we understand their importance in time, the new means of communication could also bring about a profound change in the social fabric towards more fraternity, and even help to resolve the problems besetting humanity today (Lévy, 1994: 9). This is a familiar theme: the great leap forward for mankind thanks to globally interconnected networks and computers is a recycled version of MacLuhan's thinking, itself informed by the telescoping of science and religion characteristic of Teilhard de Chardin and, as we have seen, of Saint-Simon's tenets on the common physiology of material and spiritual webs. David Forest's thinking, though, is not so much genealogical as an attempt to track the idea of "collective intelligence" through a maze of political, economic and legal discourses where the keynote, from Michael Hardt and Toni Negri to Yann Moulier-Boutang, is intoned to the score of "cognitive capitalism", and which combine the idea of "new anthropological realities" with the promotion of a "society based on contracts", an apology of deregulation and suspicion of any limitations imposed by intellectual property rules on the circulation of works in an economy built on abundance and mobility. In which we see that the idea of "collective 
intelligence" and its avatars - concepts whose plasticity and ubiquity reconciles anarchists and communists, liberals and libertarians, and supporters of open-source software - appear not only as advertising propaganda for electronics industries and virtual worlds, but also closely match the neo-liberal creed as it spread through different channels, in the 1980s and 90s, along with its lexicon that would have such far-reaching consequences for political structures and mental health: mobility, assessment, creativity, innovation, fluidity, responsibility, flexibility and so on, all denoting ways of being in society or representations of society where communication, as conditioned by the electronic paradigm, is clearly geared to the performative. Is there a pathology of communication? Yes, according to David Forest, if the idea is understood not as the obverse of "healthy" communication but rather as a permanent interplay between the visibility and invisibility of a symptom affecting a social fabric that has been deeply penetrated by the ideologies of communication. Ideologies that, like all others, are built into a political and economic vision of the world that endows it with powerful means for imposing their dictates, but also of constructing social reality - with the now familiar trail of damage that Axel Honneth (2006: 181) had in mind when, in his interview with Olivier Voirol in 2001, he advocated an analysis of society geared to a diagnosis of social pathologies aided by the concept of recognition, which would, as he explained, make it possible to show that neoliberal capitalism is moving in a direction that would significantly damage the conditions we all need for self-realisation - for example through the general trend towards commodification, the undermining of personal relationships and the increasing demands of "identity management".

8 In the case of "collective intelligence" and its ramifications, the pathology in question, however powerful, is still in a sense external to the act of communication: its conception, its political spawning ground, its suitability to a particular technical and economic context and its ideological profitability stem more from its semantic charge than from any pragmatic necessity. This is the focus of the contributions from Christine and Véronique Servais, who specialise respectively in the aesthetics of the media and the anthropology of communication, which is why they feature, significantly, at the beginning of this issue. Common representations of communication link its "success" to the efficient transmission of a message, so that the effects produced that conform to the intentions of the "sender" and ensure mutual understanding between sender and the recipient, who are assumed not only to understand the same code but also to belong to the same world of representation. It is this received idea, which has given rise to so many of the usual models of communication as well as to the excessive privilege give to the idea of "consensus", which is questioned by Christine and Véronique Servais, in the light of communication systems between humans and animals (as observed in this case in certain "enchanted encounters" between people and dolphins in the wild) and with the aid of the concepts of "dispute", "disagreement" and, to a lesser extent, "difference ", borrowed in turn from Jean-François Lyotard, Jacques Rancière and Jacques Derrida, and which all, in various ways, encompass the question of otherness and the acknowledgement of otherness in the act, and in the situation, of communication. The authors argue, through a discussion of accounts of these encounters and close cross-analysis of these philosophical concepts with the work of the linguist Antoine Culioli, the anthropologist Franco La Cecla and the contributions of Gregory Bateson and the Palo Alto school, that considering communication in terms of efficient transmission and shared worlds is tantamount to saying that intentional manipulation is a legitimate ideal in communication, and obliterates the fact that misunderstanding could actually, and 
paradoxically, be its fundamental structure insofar as it is the condition under which otherness emerges and is maintained during the interaction. The authors argue that ignoring this structure has psychopathological consequences - through control by the partner and negation of their otherness -or their politics - because a dominant idiom is imposed: the desire to eliminate misunderstanding, to resolve it by referring to a rule, is always the point where domination appears, and continues as long as the dominated partner is unable to make a point in the language of the dominant partner and to speak from a position which is not their own, in which case the interaction turns into political conflict in the strict sense. They plead in favour of communication as a concept founded on real plurality; not in terms of shared worlds, which brings in the notion of hegemony in representations and language, but rather in terms of dividing lines between, and within, the interacting partners, a kind of distance and difference between selves that is essential even for a relationship with the other to be possible.

Is censorship a pathological distortion of the communication process under political, moral, economic or religious constraint, or is it an essential component of communication? The question may seem surprising for two reasons. Censorship, first, is supposed to have disappeared, at least in its preventive form, in our democratic regimes dedicated to transparency and the free circulation of ideas; secondly, it seems obvious that relationships between censorship and communication can only stem from purely external factors - authoritarian repression, or at least control, on the one hand, and constant efforts towards free expression on the other. As a historian of the press, Laurent Martin first dismisses the idea that, if we are to believe the narrative of emancipation that goes hand in hand with the history of liberal societies, censorship has retreated from our public sphere. Rather, it has shifted, gradually and in stages, as if following the media system's transformations to reach broader potential audiences, from the printed book (16th to 18th century), to theatre and the periodical press (19th and 20th centuries), audiovisual media (20th century) and finally to the internet. And while censorship has largely shifted downstream to sanction abuses of the freedom of expression, its earlier form is still active within the film review board that was established in 1919 in France, a country where, according to Pierrat (Pierrat, 2008: 19), the law was so strict that specialised lawyers would say that if a "message" could be broadcast in France, it could be broadcast virtually anywhere else in the world with impunity. Finally, blunted and softened but always possible, censorship is still just as effective in the various forms of self-censorship and self-regulation. Taking a different slant, to discuss censorship as integral to the process of communication itself is to bring in all of the work, inspired by Roland Barthes, Michel Foucault or Pierre Bourdieu, on the processes of filtering ideas that are imposed by the order of language and discourse but also by patterns of compromise, the social process of verbal euphemisation, the formats and the norms imposed on expression by the particular structures and expectations of each field in which, and for which, it is formulated: this "structural" or "invisible" censorship promotes orthodox opinion and, ultimately and paradoxically, produces a shift from the idea of censorship as pathological to the idea that it is a normal form of communication whose role is to interiorise the constraints it has to obey in order to be accepted, received and understood, if not originally conceived. But there is a considerable risk, assuming that censorship is ubiquitous and always already at work, of establishing it as such a diffuse and permanent force that it becomes impossible to identify, of suppressing the various forms it can adopt and of disarming criticism by making it pre-emptively inoperative. To Laurent Martin, it may be preferable, for purposes of scientific and 
political analysis, to restrict the term of censorship to properly attested examples of authoritarian intervention in communication between a sender and a recipient and, in order to treat the pathology, to encourage the use of therapeutic vigilance on the part of the players concerned, as far as and including the enactment of rules to prevent abuses of censorship.

Élise Vandeninden, a researcher in cultural mediation, sheds light on yet other forms of pathology on the basis of a survey on art therapy. As she uncovers tensions between its different conceptions, she also brings out a form of investment shared by the various practitioners: creation is a "tool" for mediation, within a care centre or with the world beyond it. Carefully keeping away from the normative, her "grammatical" approach, following Luc Boltanski (2004), is based on a corpus of work on art therapy and used to map out salient patterns of activity that involve relationships between the sender, the mediator and the different recipients, whether individuals or groups. She also shows that each process of this type has a corresponding, assumed, therapeutic value. These are the patterns on which Élise Vandeninden focuses her survey among a sample of art therapists, using an entirely pragmatic sociological approach that brings out the testing power of experience in context. The particular value of her results lies in showing the hiatus between the patterns used as a model and their implementation, and sometimes doubts among these practitioners as to the reality of their therapeutic value, with some even claiming "purely aesthetic aims". These discrepancies are interpreted in the light of the trajectory and position of each agent in the artistic and medical fields, with the latter predominating. Her analyses produce the convincing hypothesis that the patient is placed by the art therapist in a paradoxical situation in which medical "art therapy", practised for purposes of mediation, is actually liable to result in a pathology of communication in which patients find themselves in what Gregory Bateson, followed by Paul Watzlawick, Janet Helmick Beavin and Don D. Jackson (1967: 195-196), called a "double bind". As for mediation centred on a more artistic, but marginal, dimension, this tends to introduce a different language within the institution and to modify the role of the patient, so that the use of art "for art's sake" in psychiatry could mean the adoption of an "interactionist" critique of mental illness - an approach in which "an attack on a hierarchy begins with an attack on its definitions, labels and conventional representations of the identity of people and things" (Becker, 1963: 229) - implying that considering art therapy from the communication angle will inevitably bring its foundations into question.

11 We come to our - necessarily open-ended - conclusion with Thomas Heller's article on recognition and governance in the workplace, which brings social pathologies back into a context and a perspective with which they are naturally associated, in other words the psycho-social afflictions besetting the supreme exemplar of control and anthropological domestication that the company workplace has become today. Building on the founding studies of Axel Honneth, the author brings out some of the processes that, in this context, produce "forms of domination linked to the quest for identity and self-realisation". From the observation that, in the world of employment, the recognition - or assertion - of the qualities of an individual or group is claimed whenever it is lacking, he shows that such recognition can also serve as an alibi for management and human resources practices to motivate the workforce. Using examples borrowed from Christophe Dejours in Souffrance en France. La banalisation de l'injustice sociale (1998) as a basis for his analysis, Thomas Heller explores how communication operates to disregard or deny recognition. In so doing, he makes a distinction between disregard and denial, in that the former is not an 
isolated practice but the foundation of an entire system, of a management strategy, while the latter appears in particular through obstacles to practices encouraging recognition. In either case, the author shows, as does Christophe Dejours, that the type of communication that presses employees, or their departments, to display themselves at their best can be used - in the name of economics - to deny the reality of their work: a distortion that, in the author's view, comes very close to contempt. Hence his hypothesis that communication, as a corporate practice for developing and disseminating messages, in effect creates obstacles to recognition and may be considered as a practice that produces forms of social pathology. From this, he draws the idea that recognition is associated with a form of managerial practice that instils a sense of self-worth in employees by encouraging self-satisfaction, in order to produce, temporarily or permanently, an effect of submission and/or performance.

In the words of Theodor W. Adorno and Max Horkheimer (1944: 22), "only thought which does violence to itself is hard enough to shatter myth". We cannot claim or even hope, in this issue, to have provided an exhaustive review, delving below the usual bland consensus on the subject, of the (more or less) symbolic forms of violence that communication can produce - not so much through its content, here, as in its structure and its efficiency as a social process or myth-embellished resource. But we believe nevertheless that together, the diversity of topics addressed in the following pages, the varied tempo of reflection, from elliptical to emphatic, the range of disciplines that provide historical, sociological, anthropological, legal and philosophical perspectives, have brought fertile ground for reflection on the very raison d'être of our publication, Questions de communication.

\section{BIBLIOGRAPHY}

Becker H., 1963, Outsiders. Études de sociologie de la déviance, trad. de l'américain par J.-P. Briand, J.M. Chapoulie, Paris, Métaillé, 1985.

Boltanski L., 2004, La condition fetale. Une sociologie de l'engendrement et de l'avortement, Paris, Gallimard.

Bougnoux D., 1993, Sciences de l'information et de la communication, Paris, Larousse.

Chateaubriand Fr. R. de, 1848, Mémoires d'outre-tombe, tomes I et II, Éd. M. Levaillant et G. Moulinier, Paris, Gallimard, 1951.

Debord G., 1967, La société du spectacle, Paris, Buchet-Chastel.

Dejours Chr., 1998, Souffrance en France. La banalisation de l'injustice sociale, Paris, Éd. Le Seuil.

Durkheim É., 1897, Le suicide, Paris, Presses universitaires de France, 1999.

Durand P., dir., 2007, Les nouveaux mots du pouvoir. Abécédaire critique, Bruxelles, Éd. Aden.

Forest D., 2004, Le prophétisme communicationnel, Paris, Éd. Syllepse.

Garrigou A., 1998, « Le secret de l'isoloir », Actes de la recherche en sciences sociales, 71-72, pp. 22-45. 
Guyau J.-M., 1885, Esquisse d'une morale sans obligation, ni sanction, Paris, Éd. Fayard, 1985.

Honneth A., 1992, La lutte pour la reconnaissance, trad. de l'allemand par P. Rusch, Paris, Éd. du Cerf, 2007.

- 2006, La société du mépris. Vers une nouvelle théorie critique, trad. de l'allemand par O.Voirol, P. Rusch, A. Dupeyrix, Paris, Éd. La Découverte, 2008.

Horkheimer M., Adorno Th.W., 1944, La dialectique de la raison, trad. de l'américain par E. Kaufholz, Paris, Gallimard, 1974.

Le Bon G., 1895, Psychologie des foules, Paris, Presses universitaires de France, 1995.

Lévy P., 1994, L'intelligence collective. Pour une anthropologie du cyberespace, Paris, Éd. La Découverte. Musso P., 1997, Télécommunications et philosophie des réseaux. La postérité paradoxale de Saint-Simon, Paris, Presses universitaires de France.

- 2003, Critique des réseaux, Paris, Presses universitaires de France. Pierrat E., dir, 2008, Le livre noir de la censure, Paris, Éd. Le Seuil. Sartre J.-P., 1983, Cahiers pour une morale, Paris, Gallimard.

Sfez L., 1988, Critique de la communication, Paris, Éd. Le Seuil, 1992.

- dir., 1993, Dictionnaire critique de la communication, 2 vol. , Paris, Presses universitaires de France.

- 2002, Technique et idéologie, Paris, Éd. Le Seuil.

Talleyrand Ch. M. de, 1967, Mémoires ou opinion sur les affaires de mon temps. Tome I : La Révolution, Paris, J. de Bonnot.

Virilio P., 1996, Cybermonde. La politique du pire, entretien avec Ph. Petit, Paris, Éd. Textuel.

Watzlawick P., Helmick Beavin J., Jackson Don D., 1967, Une logique de la communication, trad. de l'américain par J. Morche, Paris, Éd. Le Seuil, 1972.

Winkin Y., 2003, La Communication n'est pas une marchandise, Bruxelles, Éd. Labor/Espace de libertés.

\section{NOTES}

1. «...vomitoires à l'usage de nouveaux Barbares qui, sortant du nord avec l'immense train des armes à feu, viendront inonder des régions favorisées de l'intelligence et du soleil »

2. «... niais[er] béatement avec des canaux, des chemins de fer, des tripotages d'art, des arrangements de lettres ; monde de machines, de bavardage et de suffisance nommée société modèle "

3. "Je ne me laisse pas éblouir par des bateaux à vapeur et des chemins de fer; par la vente des produits des manufactures et par la fortune de quelques soldats français, anglais, allemands, italiens enrôlés au service d'un pacha : tout cela n'est pas de la civilisation »

4. "C'est à quoi tendent les mass media, best seller, book of the month, best record, Gallup, Oscar, etc. Il s'agit de présenter à l'exemplaire isolé l'image de la totalité. Naturellement on n'obtiendra que la majorité. Mais la majorité est donnée comme l'expression de la totalité. [...] L'opinion demeure dehors, elle est le point idéal et transcendant de jonction de toutes les consciences, mais précisément parce qu'elle est un transcendant, elle isole chaque conscience en face d'elle-même, sans lui laisser de mots ni de concepts pour s'exprimer "

5. Guy Debord, the author of La Société du spectacle summed this up forcefully in the idea that while isolation is the necessary condition of technology, technology in return brings isolation [ L'isolement fonde la technique, et le processus technique isole en retour] (Debord, 1967: 21), suggesting, 
in this context and denying the myth surrounding communication technologies, that there is a recursive loop between these technologies, which are supposed to bring people together, and the isolation of social subjects.

\section{AUTHORS}

\section{PASCAL DURAND}

Institutions culturelles et information

Université de Liège 